\title{
Effects of seeding date and seeding rate on yield, proximate composition and total tannins content of two Kabuli chickpea cultivars
}

\author{
Roberto Ruggeri, Riccardo Primi, Pier Paolo Danieli, Bruno Ronchi, Francesco Rossini \\ Department of Agriculture and Forestry Science, University of Tuscia, Viterbo, Italy
}

\begin{abstract}
Experiments were conducted in open field to assess the effect of seeding season and density on the yield, the chemical composition and the accumulation of total tannins in grains of two chickpea (Cicer arietinum L.) cultivars (Pascià and Sultano). Environmental conditions and genetic factors considerably affected grain yield, nutrient and total tannins content of chickpea seeds, giving a considerable range in its qualitative characteristics. Results confirmed cultivar selection as a central factor when a late autumn-early winter sowing is performed. In effect, a more marked resistance to Ascochyta blight (AB) of Sultano, allowed better agronomic performances when favourable-to-AB climatic conditions occur. Winter sowing appeared to be the best choice in the Mediterranean environment when cultivating to maximise the grain yield $(+19 \%)$. Spring sowing improved crude protein $(+10 \%)$ and crude fibre $(+8 \%)$ content, whereas it did not significantly affect the accumulation of anti-nutrients compounds such as total tannins. The most appropriate seeding rate was 70 seeds $\mathrm{m}^{-2}$, considering that plant density had relatively little effect on the parameters studied.
\end{abstract}

\section{Introduction}

Chickpea (Cicer arietinum L.) is an annual grain legume traditionally cultivated in semi-arid tropics (Asia and India), Australia and Mediterranean regions and has recently extended its

\footnotetext{
Correspondence: Roberto Ruggeri, Department of Agriculture and Forestry Science, University of Tuscia, Via San Camillo de Lellis snc, 01100 Viterbo, Italy.

E-mail: r.ruggeri@unitus.it
}

Key words: Anti-nutrients; Ascochyta blight; Chickpea; Sowing rate; Time of sowing.

Received for publication: 5 December 2016.

Revision received: 23 February 2017.

Accepted for publication: 3 March 2017.

CCopyright R. Ruggeri et al., 2017

Licensee PAGEPress, Italy

Italian Journal of Agronomy 2017; 12:890

doi:10.4081/ija.2017.890

This article is distributed under the terms of the Creative Commons Attribution Noncommercial License (by-nc 4.0) which permits any noncommercial use, distribution, and reproduction in any medium, provided the original author(s) and source are credited. acreage and cultivation area to higher latitudes (Knights et al., 2007)

Chickpeas, as other pulses, play a significant role in human and animal diets, especially as protein and energy source.

The major constraint to chickpea cultivation is represented by Ascochyta blight (AB), a necrotrophic disease caused by the fungus Ascochyta rabiei (Pass.) Labrousse. Several epidemics of AB causing complete yield loss have been reported in Pakistan, India, European countries and Mediterranean regions (Jettner et al., 1999). Also, the occurrence of bioactive compounds with antinutritional effects, such as phenolic compounds (tannins), may represent a limiting factor for chickpeas consumption. In fact, especially in monogastric animals, nutrient absorption from the gastrointestinal tract can be impaired, with the onset of detrimental effects on health and growth (Muzquiz and Wood, 2007; Verma et al., 2013). Conversely, these secondary compounds appear to be largely inactivated by rumen fermentation (Bampidis and Christodoulou, 2011).

The content of anti-nutrients and the proximate composition of chickpeas under different treatments have been widely investigated (Singh et al., 1991; Attia et al., 1994; Rincón et al., 1998; El-Adawy, 2002; Nikolopoulou et al., 2006). There has also been different studies on the effect of genotype, growing season and agronomic technique on chickpea growth and grain yield under rainfed conditions (Brown et al., 1989; Horn et al., 1996; Koutroubas et al., 2009). However, limited knowledge exists on the combined influence of environmental and agronomic factors on the proximate composition and anti-nutrients content of chickpeas. Saxena (1984) and López-Bellido et al. (2008) reported on the dramatic increases in yield obtainable by winter planting of $\mathrm{AB}$ tolerant and low-temperature tolerant kabuli chickpea, but they did not comment on quality parameters.

Bampidis and Christodoulou (2011) reported on factors influencing chickpea grain protein utilisation and some processing techniques to improve the nutritional value of chickpea. Anyway, in this review no data were presented about the effect of agronomic techniques on grain yield, proximate composition and content of secondary compounds.

Singh et al. (1990) studied the combined effect of growing season, location and planting time on hundred seed weight (HSW), protein content (PC) and cooking time (CT) of different chickpea genotypes. The authors related these quality parameters with environmental conditions and found that winter planting decreased PC by $8 \mathrm{~g} \mathrm{~kg}^{-1}$, whereas HSW increased by $1.2 \mathrm{~g}$ per 100 seeds as compared with spring planting. However, in this research no data were presented about other nutritional parameters (e.g. crude fat, starch, crude fibre, aminoacidic profile, etc.) and anti-nutrients content.

Oluwatosin (1999) and Nikolopoulou et al. (2006) found that the variability in the levels of some antinutritional factors (i.e. tannins and phytic acid) in chickpea and cowpea seeds depends largely on the environment where they are grown. Moreover, both 
authors indicated a high degree of heritability for all studied parameters. One way to change the environmental variables where a plant grows is to change the sowing date. Sowing practices have often been studied to determine the best time to plant for optimum yields. Although yield is still a crucial factor, studying how sowing date affects chemical and nutritional composition of seeds, may be helpful in achieving the desired quality of the product. Sowing date and densities have already been reported to influence the chemical composition of different legume crops such as chickling vetch (De Falco and Pardo, 1999; Rao and Northup, 2008), bean (Greven et al., 2004; Getachew et al., 2015), green field pea (Gubbels, 1977), faba bean (Hegab et al., 2014), soybean (Li, 2014) but, according to our knowledge, no data are available for chickpea. Hence, the aim of this study was to verify the hypothesis that different seeding practices (time and rate) can affect not only grain yield, but also nutritional composition, total tannins content and the susceptibility to Ascochyta blight of two chickpea cultivars (Sultano and Pascià) currently cultivated in the Mediterranean basin.

\section{Materials and methods}

\section{Experimental set up and plant growing conditions}

Two chickpea Italian varieties were used in the experiments: Sultano and Pascià. They were chosen to verify their adaptability to winter sowing, assessed mainly as resistance to Ascochyta rabiei and to represent a range of genetic variation in morphological traits (Paolini et al., 2006). Information on these varieties are reported in Table 1. To test the effects of sowing date and seeding density on grain yield and chemical composition of the two cultivars, a randomised complete block design experiment with three replicates was performed in 2006-2007 (Trial 1) and 2007-2008 (Trial 2) growing seasons. Both the trials were carried out under the same Mediterranean area (Tarquinia, Central Italy, $42^{\circ} 11^{\prime} \mathrm{N}, 11^{\circ} 45^{\prime} \mathrm{E}, 22$ $\mathrm{m}$ a.s.1.). Soil tillage consisted of one pass of mouldboard plough at $0.3 \mathrm{~m}$ depth followed by disk harrow and spring harrow.

The early seeding (hereinafter referred to as winter) was carried out on 28 December 2006 and 18 December 2007 for Trial 1 and Trial 2, respectively. The late seeding (hereinafter referred to as spring) occurred on 2 March 2007 and 14 March 2008 for Trial 1 and Trial 2, respectively. Two seeding rates, 70 and 110 seeds $\mathrm{m}^{-2}$, were compared only in Trial 2 . They were chosen depending on normal and high-yielding situations in Mediterranean-type environments (Pande et al., 2006). In Trial 1, 70 seeds $\mathrm{m}^{-2}$ was applied.

Individual plots ( $8 \times 1.5 \mathrm{~m}$ each) consisted of six rows with a row spacing of $0.3 \mathrm{~m}$ and a seeding depth of approximately $30 \mathrm{~mm}$. Diammonium phosphate (18-46-0) was applied before sowing at the rate of $200 \mathrm{~kg} \mathrm{ha}^{-1}$, and weed control was achieved by using a pre-emergence herbicide at the rate of $2 \mathrm{l} \mathrm{ha}^{-1}$ (Pendimethalin $322 \mathrm{~g} \mathrm{~L}^{-1}+$ Imazethapyr $22 \mathrm{~g} \mathrm{~L}^{-1}$ ). In both Trial 1 and Trial 2, neither irrigation nor pesticides were applied.

The chemical and physical characteristics of soil were: $33 \%$ clay, $19 \%$ silt and $48 \%$ sand, $\mathrm{pH} 6.8,0.96 \%$ organic matter and $0.054 \%$ total N. Preceding crop for both trials was durum wheat.

Meteorological data are shown in Table 2. Both for Trial 1 and Trial 2, the mean air temperature during crop growing season was about $16^{\circ} \mathrm{C}$ for winter sowing and about $18^{\circ} \mathrm{C}$ for spring sowing. Considering winter sowing, total rainfall registered during the chickpea growing season was $227 \mathrm{~mm}$ and $307 \mathrm{~mm}$ for Trial 1 and Trial 2, respectively; whereas, with regard to spring sowing, it was $134 \mathrm{~mm}$ and $162 \mathrm{~mm}$ for Trial 1 and Trial 2, respectively.

\section{Ascochyta blight scoring}

The reaction to disease was recorded each month starting from 40 days after emergence on 6 randomly selected plants per plot, using a 1-9 rating scale (Kimurto et al., 2013), in which the disease score (DS) was graded from no visible symptoms to aerial part (1) to $100 \%$ of plants killed (9). Based on the DS, cultivars were categorised for their resistance to A. rabiei infection according to the Pande et al. (2006) scale, where 1, asymptomatic; 1.1-3.0, resistant; 3.1-5.0, moderately resistant; 5.1-7.0, susceptible; and 7.19.0 , highly susceptible. The whole plant disease ratings were averaged across plants and date, to generate mean values of the disease rating for the two varieties before analysis.

\section{Harvesting and sample preparation}

Harvesting was performed using a plot harvester after physiological maturity, when about $90 \%$ of plants were completely dry

Table 1. Details of the two chickpea varieties tested.

\begin{tabular}{lcccc} 
Variety & Seed weight $(\mathrm{mg})$ & Seed type & Plant habit & Resistance to Ascochyta rabiei \\
Sultano & 320 & Smooth & Erect & Yes \\
Pascià & 550 & Rough & Semi-erect & Yes \\
\hline
\end{tabular}

Table 2. Minimum, average and maximum temperature, relative humidity and rainfall of chickpea growing season for the years 2007 and 2008. Weather data were collected from Latium Region - Agricultural Department Agro-Meteorological Station, which is located $100 \mathrm{~m}$ away from the experimental fields.

\begin{tabular}{|c|c|c|c|c|c|c|c|c|c|c|}
\hline & $\operatorname{Tm} \min \left({ }^{\circ} \mathrm{C}\right)$ & $\operatorname{Tavg}\left({ }^{\circ} \mathrm{C}\right)$ & $\begin{array}{c}2007 \\
\operatorname{Tmax}\left({ }^{\circ} \mathrm{C}\right)\end{array}$ & RH (\%) & Rainfall (mm) & $\operatorname{Tmin}\left({ }^{\circ} \mathrm{C}\right)$ & Tavg $\left({ }^{\circ} \mathrm{C}\right)$ & $\begin{array}{c}2008 \\
\operatorname{Tmax}\left({ }^{\circ} \mathrm{C}\right)\end{array}$ & RH (\%) & Rainfall (mm) \\
\hline January & 5.5 & 10.6 & 16.5 & 85 & 26.7 & 5.1 & 9.8 & 15.3 & 86 & 49.9 \\
\hline February & 5.4 & 10.7 & 16.9 & 82 & 66.1 & 3.8 & 9.1 & 15.7 & 80 & 38.3 \\
\hline March & 6.7 & 11.8 & 18.0 & 79 & 54.5 & 5.8 & 11.2 & 17.2 & 90 & 71.7 \\
\hline April & 8.6 & 15.5 & 22.5 & 80 & 17.5 & 8.5 & 14.3 & 20.5 & 86 & 36.4 \\
\hline May & 12.0 & 18.8 & 25.2 & 79 & 50.4 & 12.6 & 18.6 & 24.7 & 82 & 74.1 \\
\hline June & 16.0 & 22.2 & 28.1 & 80 & 10.8 & 15.3 & 21.9 & 27.6 & 87 & 14.4 \\
\hline July & 15.8 & 24.1 & 30.8 & 71 & 0.6 & 17.4 & 24.7 & 30.6 & 82 & 2.4 \\
\hline
\end{tabular}

Tmin, minimum temperature; Tavg, average temperature; Tmax, maximum temperature; RH, relative humidity. 
(on 30 July 2007 for Trial 1 and 1 August 2008 for Trial 2). After thorough cleaning and removal of foreign material, the grains were stored in paper envelopes at room temperature $\left(22 \pm 2^{\circ} \mathrm{C}\right)$ until drying. Seeds were analysed for dry matter (DM) drying at $65^{\circ} \mathrm{C}$ for $48 \mathrm{~h}$ in a forced air oven before grinding through a mill (Retsch, Haan, Germany) to pass $1 \mathrm{~mm}$ screen. After thoroughly mixing, milled samples were stored in sealed polyethylene containers until analysis.

\section{Analytical procedures}

Crude protein $(\mathrm{CP})$, ether extract (EE), crude fibre (CF) and ash were determined according to AOAC Official Methods 984.13 (A-D), 920.39, 978.10 and 942.05 (AOAC, 2006) respectively. Total starch (TS) concentration was determined by amyloglucosidase- $\alpha$-amylase method (AOAC Official Method 996.11) (AOAC 2006) using a commercial kit (Total Starch, AA/AMG, Megazyme International Ireland, Wicklow, Ireland). The amino-acidic profile was obtained by reverse phase liquid chromatography (RP-HPLC) on sample hydrolysates following the method developed by Cohen and De Antonis (1994), as modified by Liu et al. (1995). Separative column, derivatising agent and chromatographic eluents were available as AccQ Tag $^{\mathrm{TM}}$ kit for HPLC (Waters Co., Milford, MA, USA). Quantification of amino acids was carried out with the external standard calibration technique using high purity L-aminoacids (Sigma-Aldrich Co., St. Louis, MO, USA). Total tannins (TT) were determined by Folin-Ciocalteu method, according to Zielinski and Kozlowska (2000). Analysis was performed in triplicate, using technical grade methanol (MetOH) and FolinCiocalteu's reagent (Sigma-Aldrich Co). The final solution was read at $725 \mathrm{~nm}$ against blank using an UV-1601 double beam spectrophotometer (Shimadzu Corp., Kyoto, Japan). A standard curve was constructed dissolving purified $(+)$-catechin hydrate $(\geq$ $96.0 \%$ ) (Sigma-Aldrich Co.) in $\mathrm{MetOH}$ to obtain four calibration standards within the range $0.03-0.30 \mathrm{mg} \mathrm{mL}^{-1}$. Total tannin content of samples was then expressed as $g$ of Catechin-Equivalents (CE) per $\mathrm{kg}$ of the sample $\left(\mathrm{g} \mathrm{CE} \mathrm{kg}^{-1}\right)$.

\section{Statistical analysis}

Response variables measured in both the experiments were subjected to ANOVA, using a year-combined randomised complete block design (McIntosh, 1983). Since different seeding densities were compared only in 2008 (Trial 2) a separate three-way ANOVA was performed just for data collected in this year with cultivar, sowing date and density as factors. Means were separated by the Fisher's least significance difference (LSD) test at the $95 \%$ probability level. Data analyses were performed using R 2.4 .0 software (RCORE, 2006).

\section{Results}

\section{Grain yield and Ascochyta blight resistance}

The effect of each treatment on grain yield and $\mathrm{AB}$ score is shown in Table 3. The cultivar $\mathrm{x}$ year interaction affected both grain yield and DS (Figure 1). Particularly, in 2007 both cultivars yielded more than $2 \mathrm{t} \mathrm{ha}^{-1}$ (2.4 for Pascià and 2.3 for Sultano), while in 2008, when climatic conditions were favourable to $A B$ spreading, grain production significantly dropped by $57 \%$ for Pascià and 35\% for Sultano.

As expected, winter sown chickpeas produced considerably more grain than did spring sown ones both in Trial 1 and Trial 2 $(\mathrm{P}<0.01$ and $\mathrm{P}<0.05$, respectively). Particularly, in Trial 1, winter

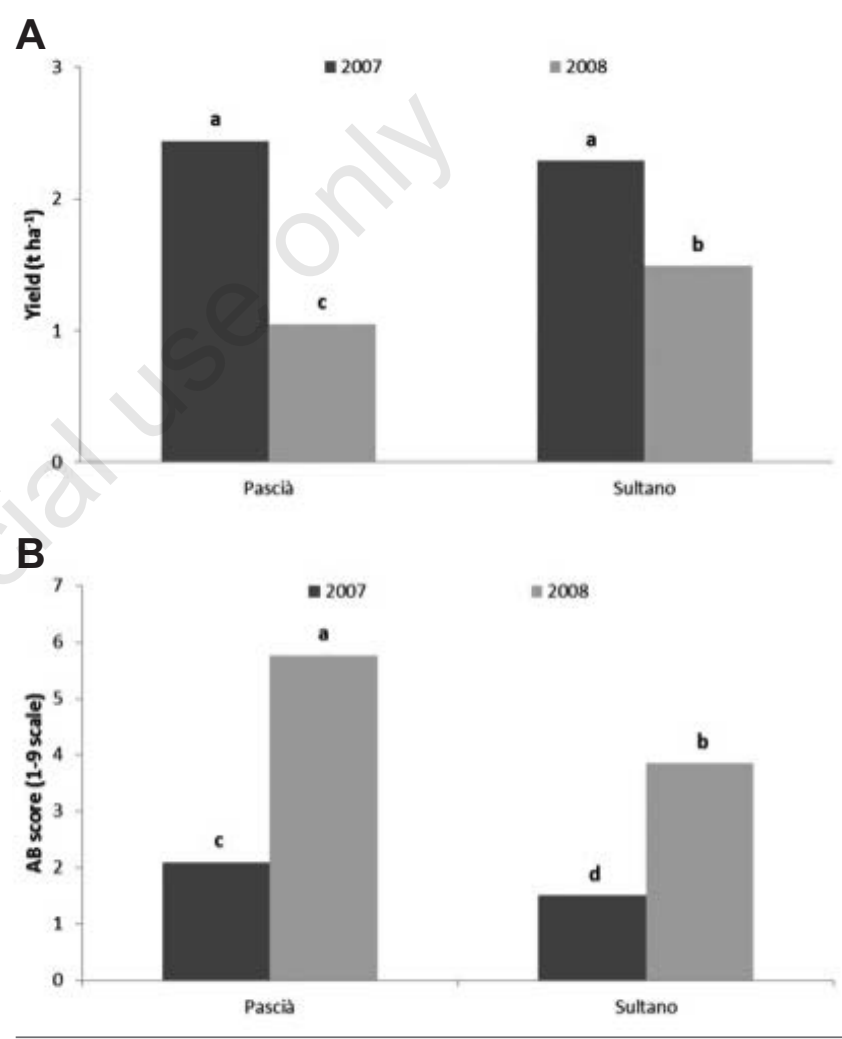

Figure 1. Grain yield (A) and Ascochyta blight score (B) as affected by cultivar $x$ year interaction. a-d: different letters indicate that the samples are statistically different, according to the Fisher's least significant difference test.

Table 3. Grain yield and Ascochyta blight score means assessed in the two trials: effect of cultivar, year and time of sowing, seeding density and their respective interactions.

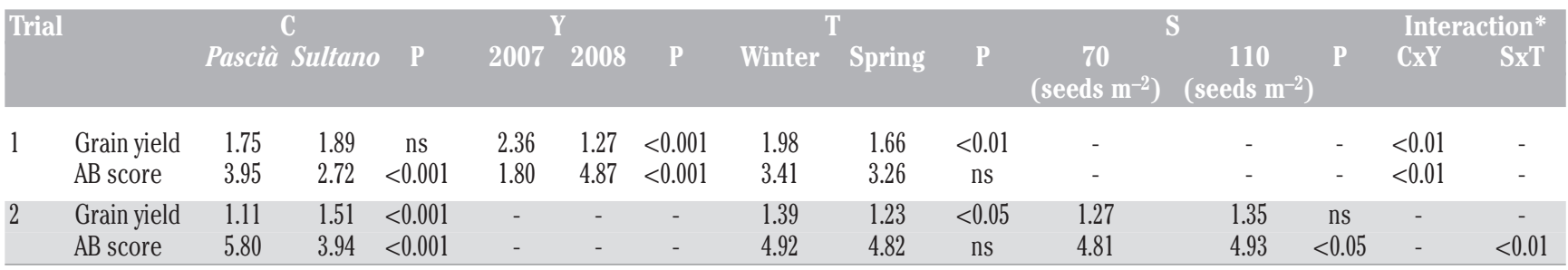

$\mathrm{C}$, cultivar; $\mathrm{Y}$, year of sowing; T, time of sowing; $\mathrm{S}$, seeding rate; $\mathrm{ns}$, not significant. ${ }^{*}$ Other interactions are not reported as they are not significant. Mean grain yields are expressed as $\mathrm{t}$ ha ${ }^{-1}$; means of Ascochyta blight (AB) score are expressed in the scale of $1-9$, where 1, no disease and 9, dead plants. Probability (P) within a single variable and row indicates that the samples are statistically different, according to ANOVA procedure. 
sowing yielded $320 \mathrm{~kg} \mathrm{ha}^{-1}$ more than spring one.

With regard to Trial 2, sowing rate did not affect grain yield whereas it significantly influenced $\mathrm{AB}$ incidence also in interaction with time of sowing (Figure 2).

In detail, significantly higher score was detected in plots sown earlier and with higher seeding density (5.1, susceptible) in comparison with other treatments that were ranked as moderately resistant (score from 4.8 to 4.9 ).

\section{Proximate composition and total tannins content}

Proximate analysis and total tannins content of chickpea seeds are reported in Table 4. Over the two years, CP content was significantly higher in 2008 than in $2007(\mathrm{P}<0.001)$ and for spring sowing date compared to winter date. The cultivar $\mathrm{x}$ time of sowing interaction significantly affected the CP accumulation (Figure 3), reaching a $17 \%$ increase in Sultano for spring sowing $(\mathrm{P}<0.01)$.

Separately, time of sowing and year affected the fat content of grain, with more fat for winter sowing $(+4.5 \%$ compared with spring date) and 2008 ( $+4.4 \%$ compared with 2007). Cultivar $x$ year interaction also influenced the fat content, with Pascià showing a significantly higher concentration in 2008 (49.9 $\left.\mathrm{g} \mathrm{kg}^{-1}\right)$ compared with 2007 (45.8 $\left.\mathrm{g} \mathrm{kg}^{-1}\right)$.

Differences in CF and ash content were observed between cultivars $($ Sultano $>$ Pascià), years $(2008>2007)$ and sowing date (spring $>$ winter for $\mathrm{CF}$ while winter $>$ spring for ash content). As for the CF content, cultivar $\mathrm{x}$ time of sowing interaction was significant (Figure 3). Sultano showed a higher CF content in delayed sowing $(+13 \%)$ and as compared with Pascià both in winter $(+12.6 \%)$ and spring sowing $(+24.8 \%)$.

Furthermore, TS content in seeds from 2008 trial was $2.7 \%$ greater $(\mathrm{P}<0.01)$ than 2007 , and Sultano contained more TS than Pascià $(\mathrm{P}<0.01)$. Cultivar $\mathrm{x}$ sowing date interaction significantly affected TS content (Figure 3). Particularly, Pascià showed 2.5\% more TS $(\mathrm{P}<0.05)$ in spring sowing than winter one $(474.0 \mathrm{vs}$ $462.3 \mathrm{~g} \mathrm{~kg}^{-1}$ ). Regarding the total tannins (TT) content, Sultano contained $25 \%$ more TT $(\mathrm{P}<0.01)$ than Pascià, while the other treatments were not significant.

\section{Amino acids content}

Aminoacid composition of chickpea seeds produced during Trial 2, grouped in essential, aromatic and sulfur amino acids, is reported in Table 5. The content of essential amino acids was affected by the sowing date $(\mathrm{P}<0.05)$ and cultivar $(\mathrm{P}<0.001)$. It was $6 \%$ greater for winter sowing than spring one and $7.4 \%$ higher for Sultano than Pascià. A sowing date $\mathrm{x}$ cultivarinter action $(\mathrm{P}<0.01)$ was observed as far as the aromatic aminoacids content is concerned. Particularly, a higher aromatic aminoacids content was detected for Sultano when sown in winter $(+38.5 \%)$. Furthermore, sowing date affected sulfur aminoacids content $(\mathrm{P}<0.05)$ showing a $33 \%$ increase for winter sowing compared with spring one.

\section{Discussion}

In this study, growing chickpea in rainfed cropping systems of the Mediterranean environment resulted in a greater yield for winter than spring sowing.

The year-to-year variability observed in grain yield could be explained by taking into account differences in weather parameters and $\mathrm{AB}$ pressure. It was demonstrated that under similar climatic conditions, the improvement in grain yield was positively affected by total rainfall and its distribution over growing season (López-

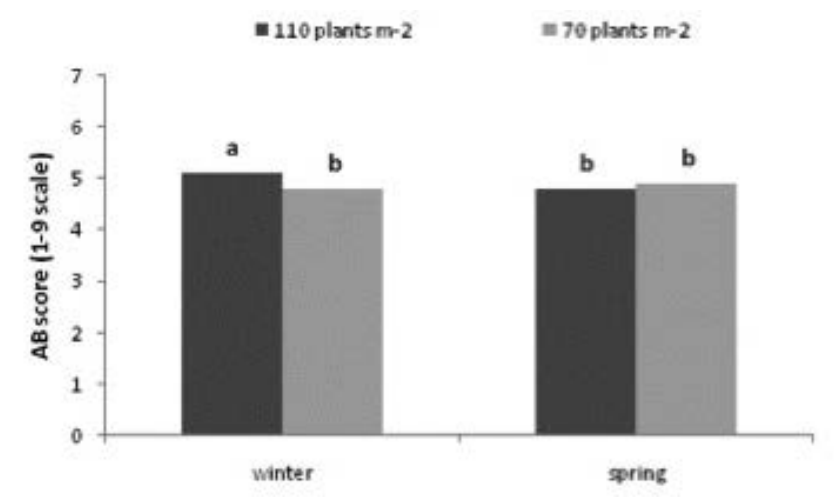

Figure 2. Ascochyta blight score as affected by sowing rate $\mathrm{x}$ time interaction. $a-b$ : different letters indicate that the samples are statistically different, according to the Fisher's least significant difference test.
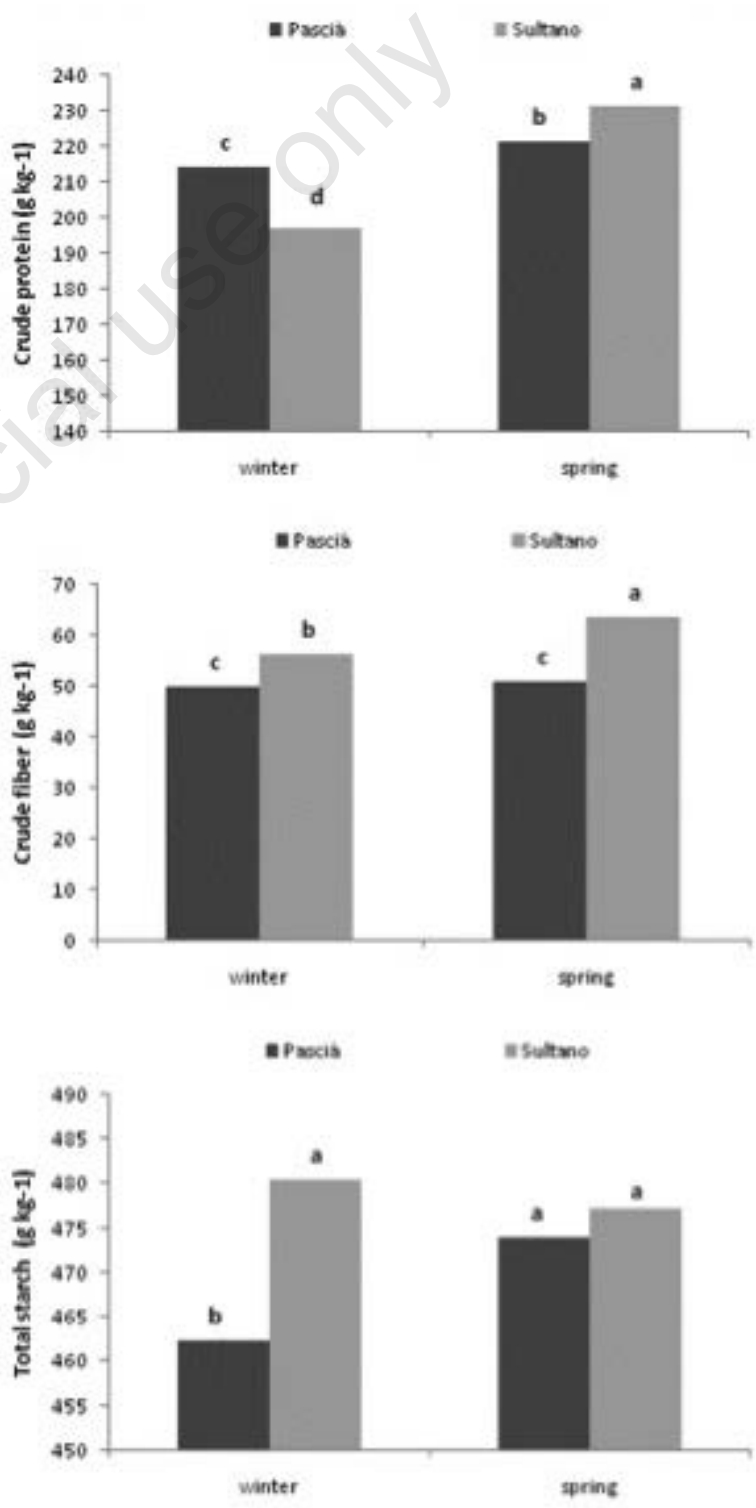

Figure 3. Crude protein, crude fibre and total starch content as affected by sowing date $x$ cultivar interaction. a-d: different letters indicate that the samples are statistically different, according to the Fisher's least significant difference test. 
Bellido et al., 2008). However, in the present study the wetter growing season $(2007 / 2008)$ was characterised by a lower grain yield than the drier one $(2006 / 2007)$. The lower yields should be attributed to a greater biotic stress occurred during the 2007/2008 growing season. Moreover, it has to be taken into account that 2007 rainfall amount was sufficient to cover the chickpea needs in the useful stages. Trapero-Casas and Kaiser (1992) noted that disease severity increases with the increase in relative humidity, cloudiness and prolonged wet weather, which were the climatic conditions observed from March to early June 2008 in the present study (Figure 1). Considering that $\mathrm{AB}$ resistance rapidly diminishes with plant age, in particular at the beginning of anthesis (Chongo and Gossen, 2001), in 2008 the disease pressure was substantially greater than in 2007 , due to almost $50 \%$ more rainfall during reproductive development (April and May).

The yield reduction observed in 2008 was much higher (57\%) in Pascià compared to Sultano (35\%). These results could be explained by the disease score observed in 2008 for Pascià (5.8), which can be categorised as susceptible versus the more resistant Sultano (score 3.9). This fact evidences that yield loss in chickpea could be strongly affected by AB outbreaks even though moderately resistant cultivars are used (Pande et al., 2006).

About sowing date, winter sowing increased yields (19\%) in comparison to spring sowing $(\mathrm{P}<0.01)$. This result confirms findings from previous studies conducted under rainfed Mediterranean conditions (Saxena, 1984; Zaiter and Barakat, 1995; LópezBellido et al., 2008). In that environment, early sowing allows the crop to take more advantage of stored soil water from late winter and early spring rain events. This opportunity, coupled with the absence of frost or disease damages, suggests that grain yield increased in long season chickpeas because leaf area duration was longer (López-Bellido et al., 2008) and water use efficiency was greater than that for late winter or spring sowings (Yau, 2005).

However, the advantages associated with early sowing can be lost when climatic conditions are unfavorable. In our study, this was particularly important during the critical growth stages, such as flowering and pod-filling, when plants had the maximum susceptibility to $\mathrm{AB}$ infection. As for differences between cultivars, Sultano (more resistant to $\mathrm{AB}$ ) shall be regarded as more advisable from an economic and environmental point of view, because it does not need fungicide applications during the growing season. Moreover, for the same reason Sultano could be more advisable for organic farming than Pascià.

In general, the proximate composition of the chickpea cultivars under study agrees with the values found in the literature. References report protein varying from 13.7 to $34.0 \%$ and fat from 3.4 to $4.6 \%$; CF, TS and ash were also in line with previously published data (Nikolopoulou et al., 2006; Bambidis and Christodoulou, 2011). Also aminoacidic profiles, observed in the present study, are in line with findings by Bampidis and Christodoulou (2011).

The effect of cultivation year on the composition of chickpeas was also reported by Nikolopoulou et al. (2006), though we observed a higher fat content in the rainy season (2008). The higher fat content could be attributed to the lower grain yield as recently found by Li et al. (2014) in soybean.

Higher CP content in delayed sowings was also reported for chickpea by Singh et al. (1990), Kaya et al. (2010) and Dehal et al. (2016). The effect of spring or autumn planting on protein content is well known in wheat, in which a delay in sowing date was asso-

Table 4. Proximate composition and total tannins content assessed in the two trials: effect of cultivar, year, time of sowing, seeding density and their respective interactions.

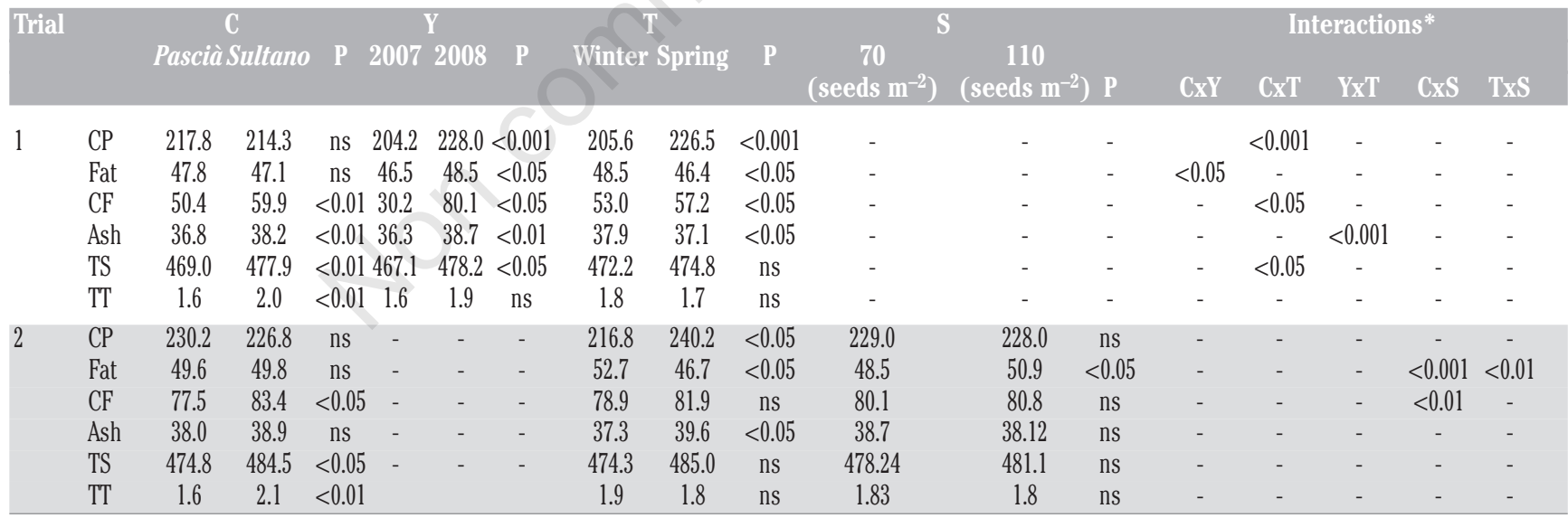

C, cultivar; Y, year of sowing; T, time of sowing; S, seeding rate; ns, not significant; CP, crude protein; CF, crude fibre; TS, total starch; TT, total tannins; NS, not significant. *Other interactions are not reported as they are not significant. Means are expressed as $\mathrm{g} \mathrm{kg}^{-1}$ on dry matter basis. Probability (P) within a single variable and row indicates that the samples are statistically different, according to ANOVA procedure.

Table 5. Amino acids compounds of seeds in trial 2: effect of cultivar, time of sowing, seeding density and their respective interactions

\begin{tabular}{|c|c|c|c|c|c|c|c|c|c|c|}
\hline \multirow[t]{2}{*}{ Trial } & \multicolumn{2}{|c|}{ C } & \multicolumn{4}{|c|}{$\mathrm{T}$} & \multicolumn{3}{|c|}{ S } & \multirow{2}{*}{ Interaction* } \\
\hline & Pascià & Sultano & $\mathbf{P}$ & Winter & Spring & $\mathbf{P}$ & $\begin{array}{c}70 \\
\left(\text { seeds } \mathrm{m}^{-2}\right)\end{array}$ & $\begin{array}{c}110 \\
\left(\text { seeds } \mathrm{m}^{-2}\right)\end{array}$ & $\mathbf{P}$ & \\
\hline Essential a.a. & 47.09 & 50.62 & $<0.001$ & 50.28 & 47.43 & $<0.05$ & 48.37 & 49.34 & ns & - \\
\hline Sulfur a.a. & 1.02 & 1.11 & ns & 1.21 & 0.93 & $<0.05$ & 0.93 & 1.21 & ns & - \\
\hline Aromatic a.a. & 8.20 & 9.33 & $<0.05$ & 9.53 & 7.95 & ns & 8.20 & 9.28 & $<0.05$ & $<0.01$ \\
\hline
\end{tabular}

$\mathrm{C}$, cultivar; T, time of sowing; S, seeding rate; ns, not significant *Other interactions are not reported as they are not significant. Means are expressed as $\mathrm{g} / \mathrm{kg}$ on dry matter basis. Probability (P) within a single variable and row indicates that the samples are statistically different, according to ANOVA procedure. 
ciated with a decrease in mean grain weight along with an increased per-grain total nitrogen content, thus leading to an overall increase in protein percentage (Motzo et al., 2007). However, taking into account the total amount of protein gained per hectare, winter sowing proved to be the best choice.

With regard to the total tannins (TT) content of chickpea seeds, Sultano contained $25 \%$ more total tannins $(\mathrm{P}<0.01)$ than largesized Pascià, thus confirming the importance of genetic effect for this parameter and the higher TT content in smaller seeds (Nikolopoulou et al., 2006).

Moreover, the finding that Sultano contained more TT than Pascià (less resistant to $\mathrm{AB}$ ), agrees with results of Kumar et al. (2013), who stated that AB resistance is related to the accumulation of phenolic compounds in chickpea seeds of different genotypes. It is well known the role of phenolics in the resistance mechanisms of plants against fungal pathogens (Lattanzio et al., 2006). Some variables such as rhizome inoculation (Abdalla et al., 2013) and row spacing (Menga et al., 2014) proved to be effective on the accumulation of phenols in chickpea. However, in our study neither the year nor the sowing date or sowing rate (only tested for Trial 2) affected TT content.

\section{Conclusions}

In summary, this study has shown that both environmental conditions and genetic factors affect not only grain yield but also the nutrient and anti-nutrient compositions of chickpea seeds, determining a considerable range in their qualitative characteristics. Time of sowing was found to affect strongly both yield and chemical composition of seeds. Winter sowing appeared to be the best choice in the Mediterranean environment when cultivating to maximise the grain yield. Moreover, even though delayed sowing improved CP content $(+10 \%)$, the total amount of protein obtainable per hectare was higher for winter planting. The cultivar Sultano proved more productive than Pascià especially when climatic conditions were favourable for $\mathrm{AB}$ outbreak, emphasising the importance of selecting $\mathrm{AB}$ resistant genotype to improve the agronomic performance of this grain legume when sown in organic cropping systems. Plant density had relatively little effect on the considered parameters.

\section{References}

Abdalla AS, Abdelgani ME, Osman AG, 2013. Effects of biological and mineral fertilization on yield, chemical composition and physical characteristics of chickpea (Cicer arietinum L.) seeds. Pakistan J. Nutr. 12:1-7.

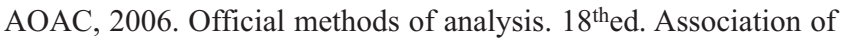
Official Analytical Chemists International, Maryland, USA.

Attia RS, El-Tabeyshehata AM, Aman ME, Hamza MA, 1994. Effect of cooking and decortication on the physical properties, the chemical composition and the nutritive value of chickpea (Cicer arietinum L.). Food Chem. 50:125-31.

Bampidis VA, Christodoulou V, 2011. Chickpeas (Cicer arietinum L.) in animal nutrition: a review. Anim. Feed Sci. Technol. 168:1-20.

Brown SC, Gregory PJ, Cooper PJM, Keatinge JDH, 1989. Root and shoot growth and water use of chickpea (Cicer arietinum) grown in dryland conditions: effects of sowing date and geno- type. J. Agric. Sci. 113:41-9.

Chongo G, Gossen BD, 2001. Effect of plant age on resistance to Ascochyta rabiei in chickpea. Canadian J. Plant Pathol. 23:358-63.

De Falco E, Pardo A, 1999. Yield and quality of ecotypes of chickling vetch (Lathyrussativus L.) as affected by sowing date in a hilly area of southern Italy. Agricoltura Mediterranea 129:12835 .

Dehal IB, Kalia R, Kumar B, 2016. Genetic estimates and path coefficient analysis in chickpea (Cicer arietinum L.) under normal and late sown environments. Legume Res. 39:510-6.

El-Adawy TA, 2002. Nutritional composition and antinutritional factors of chickpeas (Cicer arietinum L.) undergoing different cooking methods and germination. Plant Foods Hum. Nutr. 57:83-97.

Getachew E, Mohammed A, Tesfaye A, 2015. Impact of sowing date and plant spacing on yield, quality and disease incidence of Snap bean (Phaseolusvulgaris L.) varieties at Jimma Southwestern, Ethiopia. Global Adv. Res. J. Educ. Res. Rev. 4:81-9.

Greven MM, McKenzie BA, Hampton JG, Hill MJ, Sedcole JR, Hill GD, 2004. Factors affecting seed quality in dwarf French bean (Phaseolus vulgarisL.) before harvest maturity. Seed Sci. Technol. 32:797-811.

Gubbels GH, 1977. Quality, yield and weight per seed of green field peas as affected by sowing and harvest dates. Canadian J. Plant Sci. 57:1029-32.

Hegab ASA, Fayed MTB, Hamada Maha MA, Abdrabbo MAA, 2014. Productivity and irrigation requirements of faba-bean in North Delta of Egypt in relation to planting dates. Ann. Agric. Sci. 59:185-93.

Horn CP, Birch CJ, Dalal RC, Doughton JA, 1996. Sowing time and tillage practice affect chickpea yield and nitrogen fixation 1. Dry matter accumulation and grain yield. Austral J. Experim. Agric. 36:695-700.

Jettner RJ, Siddique KHM, Loss SP, French RJ, 1999. Optimum plant density of desi chickpea (Cicer arietinum L.) increases with increasing yield potential in south-western Australia. Austral. J. Agric. Res. 50:1017-25.

Kaya M, Sanli A, Tonguç M, 2010. Effect of sowing dates and seed treatments on yield, some yield parameters and protein content of chickpea (Cicer arietinum L.). African J. Biotechnol. 9:3833-9.

Kimurto PK, Towett B, Mulwa RS, Njogu N, Jeptanui LJ, Rao GNVPR, Silim S, Kaloki P, Korir P, Macharia JK, 2013. Evaluation of chickpea genotypes for resistance to ascochyta blight (Ascochyta rabiei) disease in the dry highlands of Kenya. Phytopathologia Mediterranea 52:212-22.

Knights EI, Acikgoz A, Warkentin T, Bejiga G, Yadav SS, Sandhul IS, 2007. Area, Production, Distribution. In: S.S. Yadav, R.J. Redden, W. Chen, B. Sharma (ed.) Chickpea Breeding and Management. Trowbridge: Cromwell Press, pp. 167-79.

Koutroubas SD, Papageorgiou M, Fotiadis S, 2009. Growth and nitrogen dynamics of spring chickpea genotypes in a Mediterranean-type climate. J. Agric. Sci. 147:445-58.

Kumar R, Appunu C, Mahadeviah C, Sreenivasa V, Waldia RS, Meena MR, Chhabra ML, 2013. Impact of ascochyta blight disease on the expression of biochemical compounds in chickpea. Legume Res. 36:268-70.

Lattanzio V, Lattanzio VMT, Cardinali A, 2006. Role of phenolics in the resistance mechanisms of plants against fungal pathogens and insects. In: F. Imperato (ed.) Phytochemistry: advances in research. Trivandrum, Kerala, India: Research 
Signpost, pp. 23-67.

Li Y, Du M, Zhang Q, Wang G, Jin J, Herbert S, Liu X, 2014. Planting date influences fresh pod yield and seed chemical compositions of vegetable soybean. Hortscience 49:1376-80.

Liu HJ, Chang BY, Yan HW, Yu HW, Liu XX, 1995. Determination of amino acids in food and feed by derivatization with 6aminoquinolyl-n-hydroxysuccinimidyl carbamate and reversed-phase liquid chromatographic separation. J. AOAC Int. 78:736-744.

López-Bellido FJ, López-Bellido RJ, Khalil SK, López-Bellido L, 2008. Effect of planting date on winter kabuli chickpea growth and yield under rainfed Mediterranean conditions. Agronomy J. 100:957-964.

McIntosh MS, 1983. Analysis of combined experiments. Agronomy J. 75:153-5.

Menga V, Codianni P, Fares C, 2014. Agronomic management under organic farming may affect the bioactive compounds of lentil (Lens culinaris L.) and grass pea (Lathyrus communis L.)? Sustainability 6:1059-75.

Motzo R, Fois S, Giunta F, 2007. Protein content and gluten quality of durum wheat (Triticum turgidum subsp. durum) as affected by sowing date. J. Sci. Food Agric. 87:1480-8.

Muzquiz M, Wood JA, 2007. Antinutritional Factors. In: S.S. Yadav, R.J. Redden, W. Chen, B. Sharma (ed.) Chickpea Breeding and Management. Trowbridge: Cromwell Press, pp. 143-66.

Nikolopoulou D, Grigorakis K, Stasini M, Alexis M, Iliadis K, 2006. Effects of cultivation area and year on proximate composition and antinutrients in three different kabuli-type chickpea (Cicer arietinum) varieties. Eur. Food Res. Technol. 223:737-41.

Oluwatosin OB, 1999. Genotype $\times$ environment influence on cowpea (Vigna unguiculata (L.) Walp) antinutritional factors: 1 Trypsin Inhibitors, Tannins, Phytic Acid and Haemagglutinin. J. Sci. Food Agric. 79:265-72.

Pande S, Krishna Kishore G, Upadhyaya HD, Narayana Rao J, 2006. Identification of sources of multiple disease resistance in mini-core collection of chickpea. Plant Disease 90:1214-8.

Paolini R, Faustini F, Saccardo F, Crinò P, 2006. Competitive interactions between chick-pea genotypes and weeds. Weed Res. 46:335-44.

R Development Core Team, R 2006. A language and environment for statistical computing, $\mathrm{R}$ Foundation for Statistical Computing, Vienna, Austria. Available from: http://www.Rproject.org

Rao SC and Northup BK, 2008. Planting date affects production and quality of grass pea forage. Crop Sci. 48:1629-35.

Rincón F, Martínez B, Ibáñez MV, 1998. Proximate composition and antinutritive sub-stances in chickpea (Cicer arietinum L.) as affected by the biotype factor. J. Sci. Food Agric. 78:382-8.

Saxena NP, 1984. Chickpea. In: R. Goldsworthy, N.M. Fisher (eds.) The physiology of tropical field crops. Chichester, John Wiley \& Sons Ltd., pp. 419-52.

Singh KB, Williams PC, Nakkoul H, 1990. Influence of growing season, location and planting time on some quality parameters of kabuli chickpea. J. Sci. Food Agric. 53:429-41.

Singh U, Subrahmanyan N, Kumar J, 1991. Cooking quality and nutritional attributes of some newly developed cultivars of chickpea (Cicer arietinum). J. Sci. Food Agric. 55:37-46.

Trapero-Casas A, Kaiser WJ, 1992. Influence of temperature, wetness period, plant age, and inoculums concentration on infection and development of ascochyta blight of chickpea. Phytopathology 82:586-96.

Verma AK, Kumar S, Das M, Dwivedi PD, 2013. Comprehensive review of legume allergy. Clin. Rev. Allergy Immunol. 45:30-46.

Yau SK, 2005. Optimal sowing time and seeding rate for wintersown, rain-fed chickpea in a cool, semi-arid mediterranean area. Austral J. Agric. Res. 56:1227-33.

Zaiter HZ, Barakat SG, 1995. Flower and pod abortion in chickpea as affected by sowing date and cultivar. Canadian J. Plant Sci. 75:321-7.

Zielinski H, Kozlowska H, 2000. Antioxidant activity and total phenolics in selected cereal grains and their different morphological fractions. J. Agric. Food Chem. 48:2008-16. 